\title{
Glory and Agony: Isaac's Sacrifice and National Narrative, by Yael S. Feldman
}

Stanford Studies in Jewish History and Culture | Stanford: Stanford University Press, 2010 | xviii + 422 pages | ISBN: 978-08047-5902-I (hardback) \$60.00

The biblical account of the near-sacrifice of Isaac in Genesis 22, known among Jews as the Aqedah (elsewhere often spelled Akedah), the binding (viz., of

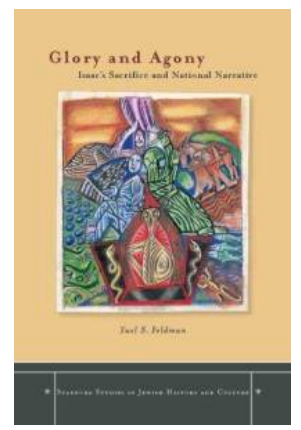
Isaac), has been the subject of considerable discussion, re-writing and reinterpretation over the centuries by Jews and others. This book by Yael Feldman presents a detailed, complex and sometimes provocative study of the way writers, poets, dramatists, critics, some scholars, and a few visual artists in the State of Israel during the last century have dealt with this account, paying some attention to other narratives of sacrifice such as that of Jephthah's daughter. The Aqedah in particular has been a major vehicle through which these writers and artists have sought to mediate between the Zionist vision and the harsh realities of war and Holocaust.

The writers and artists dealt with are almost all secular and politically left-wing. Therefore, these narratives function for them more as national narratives than as religious scripture and the author regularly speaks of the Aqedah as a literary "trope." A degree of sacrality still attaches to the "trope," however, much as some would like to escape this. The paradox is expressed by the poet Gouri: "We are full of religious symbols without believing in God" (248). At the same time, the trope is sufficiently free of sanctity to be able to be handled in a very wide variety of ways. Sometimes the outlines of the Aqedah narrative are quite recognizable, sometimes parts are omitted or changed (God and the angel rarely appear) or mixed with other tropes. Sometimes there is just a brief reference to it. Sometimes it is only implicit, to be discovered contestably by the author and other critics. Sometimes the treatment draws a positive message from the trope, often it draws an ambiguous one and sometime quite a negative one, as when the character in a novel says, "I hate our father Abraham for going to bind Isaac ... I hate the God that sent him to bind" (I72). Often the Freudian Oedipus complex is mapped onto the Aqedah, although many reject this. Christian ideas have some influence at points and the name of Søren Kierkegaard is often invoked as is that of Alexander Herzen, the Russian revolutionary. Modern 
writers such as Jacques Derrida are invoked by the author for comparative and explanatory purposes.

There are three major versions of the Aqedah in traditional Jewish literature: the Biblical account in which Isaac is silent; post-Biblical accounts in which Isaac accepts his fate and actively cooperates; and later medieval accounts produced in times of extreme persecution in which Isaac actually is sacrificed, made known particularly by Shalom Spiegel in The Last Trial. It is the second of these versions that most often underlies the accounts in this book.

The format of the book is historical. The Aqedah came to be the "focal" sacrificial trope (20) about 1940. In the two decades before this the self-bound Isaac appeared occasionally as a model of active self-sacrifice for the nation in contrast to the passive martyrdom of the past. A bit earlier the phrase osher aqedah (bliss of Aqedah) was coined in connection with the Jewish Legion in World War One, though it lay dormant until revived in a Passover Haggada in I949. The author engages in some interesting literary sleuthing to trace osher to a term in Russian Orthodox theology that means, roughly, "spiritual struggle" (95).

During the I 940 s the Aqedah evolved into "the core narrative of the birth of the nation" (I 49) and the focus was largely on the moral dilemma faced by Abraham, reflecting the agony experienced by the settlers' generation, who had to send their sons to war to gain independence. In these versions, the sons or daughters usually go willingly and the action of the "Abrahams" is reluctantly and agonizingly justified. Even the son who expresses hate for father Abraham accepts and embraces his fate (I74-75). The trope could also, however, invoke the passive suffering of the Holocaust and part of its power lies in its ability to invoke both passive and active sacrifice.

From the late I950s, there is more focus on Isaac as the sacrifice and more criticism of Abraham. Isaac is more likely to be an unwilling victim, and intergenerational conflict is more prominent. By the mid I96os, Freudian interpretations become predominant. After 1967 there is something of a return to earlier themes along with more critical treatments. In the I970s and I 980 os there are several presentations of Abraham as a violent and destructive figure and Isaac as too passive, a tendency intensified by the Lebanon War in 1982. In that year, Yehuda Amichai, a popular poet, declared that the real hero of the Aqedah was the ram, here understood as the foot soldiers who bear the brunt of war. In 1983 a drawing by Menashe Kadishman, an internationally recognized artist, featured a menacing lamb with a supine 
Isaac. Some writers also note the parallel between Isaac and Ishmael, who is expelled by his father. After the assassination of the prime minister Yitzhak Rabin in 1995 and the events of 9/I I in 200 I, treatments of the Aqedah return to the theme of sacrifice, whether commending or opposing it.

While the story of the Aqedah is a very male affair and most of the writers and artists dealing with it are men, the author makes sure that female voices and perspectives are heard. An interesting example is Shulamit Hareven, a peace activist. In 1970 she complained that the "Isaac generation," the children of the kibbutzim, was passive and lacking in self-confidence, hemmed in by its parents. In 1976 she argues that, although the Aqedah enshrines violence, it in fact represents the Jewish refusal to accept the myth of primal violence. By 1994, however, she presents it as a dangerous myth and violence as a male problem, to be countered by the efforts of women. Soon after this she became part of the Women for Peace movement.

This brief summary only begins to suggest the variety and complexity of the material covered in this book. The historical periodization is not so clear in the book as I have tried to make it here because the author regularly presents early adumbrations of later trends and later continuations of earlier trends, as well as inserting material from a different period from that being treated when in his view it illuminates the material at hand.

This book is not merely a recording of interpretations of the Aqedah but also represents a major interpretive effort by the author and constitutes a contribution to the process being described. Her choice of material certainly does not represent Israeli society or even Israeli literature as a whole. She sometimes indicates that authors or items discussed were little known at the time or have been largely forgotten. These items appear evidently because of the author's interpretative needs. Since she presents mainly left-wing writers, one wonders what the right wing has been thinking and writing. The author gives us an idea in her discussion of a 1992 article by Moshe Shamir, a formerly left-wing novelist who had become right wing by this time. He accepts the label of Isaac for the 1948 generation (his own) and admits that it was passive but stresses its loyalty and sense of responsibility, true to the Isaac of Jewish tradition. One wonders which was more prevalent in Israeli society at the time, this view or the left-wing view of Isaac as obsessively obedient to an obsessively belligerent father. It also should be noted that the current generation of writers appears underrepresented. Few writers born after 1940 are discussed and the period after 1995 is dealt with in summary fashion in an eight-page "Afterword." 
This book is definitely an "insiders" book, in that the author presumes considerable knowledge of the Israeli literary scene on the part of the reader. For one like me, who has considerable interest in the Aqedah and reasonable knowledge of Jewish and Israeli political, cultural and religious, but not literary history, it has been hard going. The author does not always give as full a description of the contents of the works discussed as I would want and will often begin a topic and then digress to another before returning to the first, something that may suit the knowledgeable reader but is confusing to the neophyte.

Anyone who knows the Israeli literary scene will find in this book an illuminating discussion of that scene and a significant contribution to it. Anyone who wants to know about the Israeli literary scene will do well to start somewhere else before undertaking this book. Anyone who is mainly interested in the Aqedah as a cross-cultural theme will find much of interest and value here but will have to work hard to get it.

William Shepard

University of Canterbury 